\title{
Metapopulations and FeEDING SELECTIVITY OF MONTANE AND LONG-TAILED VOLES (Microtus montanus AND M. longicaudus), AND HaNTAVIRUS AND Plague IN THE JACKSON Hole SMall Mammal Community
}

\author{
FREDERICK J. JANNETT, Jr. $\downarrow$ DEPARTMENT OF BIOLOGY \\ SCIENCE MUSEUM OF MINNESOTA AND \\ DEPARTMENT OF FISHERIES AND WILDLIFE \\ UNIVERSITY OF MINNESOTA $\uparrow$ ST. PAUL
}

\section{$\downarrow$ OBJECTIVES}

The purpose of the long-term research which began in 1971 on metapopulations of voles is to enumerate patterns in survivorship, reproduction, and morphology across sections of the metapopulations. The study sites for Microtus montanus were chosen to represent primary and secondary habitat, and proximate and isolated habitat patches.

The purpose of the work which commenced in 1989 is to ascertain how selectively Microtus montanus and $M$. longicaudus feed, and to assess vegetation as a factor in demographic processes of the two species.

The purpose of the more recently initiated study on hantavirus started in 1994 is to ascertain the extent of hantavirus among as many species of small mammals as possible, to identify the strain(s), to understand the presence of hantavirus across species and among the metapopulations of voles, and to assess the potential for human contact. The purpose of the work on plague since 1995 is to test the long-standing hypothesis that voles are a reservoir in the intervals between plague outbreaks among ground squirrels.

\section{$\uparrow \quad$ METHODS}

Most trapping periods were limited to two days so that impact on the respective populations would be minimized. From fresh specimens of voles, eyes were removed for age determination based upon lens weight (Gourley and Jannett, 1975).

In 1995, we undertook standard monitoring efforts on nine known populations of Microtus montanus and on two populations of $M$. longicaudus for long-term metapopulation data; an unstructured sample was made on one other known $M$. montanus population. No effort was made to enumerate additional populations of $M$. longicaudus or to begin the detailed work on food habits, because the emphasis in the field effort was placed on securing as many species as possible through live-trapping for the hantavirus survey.

Specimens were obtained for the hantavirus and plague surveys in the 10 long-term study populations of Microtus montanus and two longterm study populations of $M$. longicaudus. They were also caught at 39 additional sites ranging as far south as three miles south of Moose and as far north as the Grassy Lake area of the Rockefeller Memorial Parkway. Collections were made in and/or around 
buildings at 17 sites, including Beaver Creek, Moose, Colter Bay, Signal Mountain, and the Research Station at the AMK Ranch. Other collecting sites were proximate to human habitation at Flagg Ranch, Elk Ranch, and the Moran grade school. Fleas were removed from most specimens and saved for identification and plague culture by Dr. Ken Gage of the Centers for Disease Control and Prevention (CDC), Ft. Collins, Colorado. For the hantavirus survey, specimens were sacrificed with an anesthetic overdose. Blood and lungs were removed and frozen, and the blood was shipped to CDC, Atlanta, where it was examined for hantavirus using ELISA.

\section{$\uparrow \quad$ RESULTS}

\section{DEMOGRAPHY OF MICROTUS}

In the nine populations of Microtus montanus monitored using standard protocols in October, 1994 and again in October, 1995, numbers of voles showed disparate changes. However, there was a general overall increase in numbers. Also, there was an increase of $1.35 x$ the 1994 numbers for the one unstructured sample in primary habitat. The changes at the other primary habitat sites were a decline by $0.28 \mathrm{x}$ and increases of $1.10 \mathrm{x}$ and $2.55 \mathrm{x}$ the 1994 numbers, the latter of these increases was probably, in part, due to snow during the 1994 sample session which reduced the numbers obtained. At sites proximate to primary habitat, numbers decreased by $0.71 x$ the 1994 numbers and increased elsewhere by $1.63 x$ and $2.67 x$, respectively. At one isolated site, the number of voles increased by $1.5 x$ the 1994 numbers. There were two sites with secondary habitat for this species; no $M$. montanus was secured at one such site; only one vole was obtained at the other site.

Fall breeding by Microtus montanus was evidenced by lactating and recently lactating females, but there were no pregnant females. Of the nine sites monitored for $\boldsymbol{M}$. montanus where voles were obtained in 1995, one or more parous females were secured at each of seven sites, and each of six of these sites had at least one female still lactating. Each of the "M. longicaudus sites" also had one or two parous $M$. montanus in the respective samples. Among the nine sites with parous females, the operational sex ratios (OSR) (males:females) of reproductively active and recently active male voles to parous females ranged from 1:1 to 1:6. Based on initial determinations of reproductive condition, there was a weak relationship between the OSR and the percentage of parous females still or recently lactating (Figure 1).

Numbers of Microtus longicaudus were characteristically low at the two sites where they had been monitored. As is usual for this species in northern Jackson Hole in October, breeding had mostly ceased.

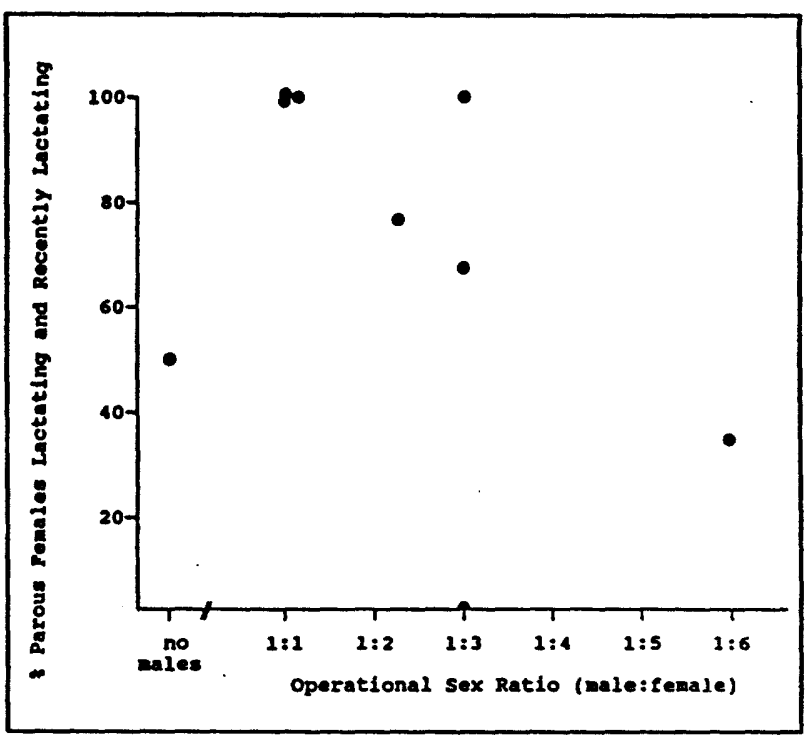

Figure 1. Distributions of operational sex ratios of Microtus montanus and percentages of lactating/recently lactating females among parous females in October samples.

\section{HANTAVIRUS AND PLAGUE}

For hantavirus, blood was examined serologically from 559 specimens in July and 661 specimens in October. The survey included 18 rodent species, two lagomorph species, one species of weasel, and at least three species of shrews (Table 1). The efficacy of the ELISA test for hantavirus in camivores and shrews is problematic. Only three species tested positive for hantavirus: Peromyscus maniculatus, Microtus montanus, and $M$. pennsylvanicus.

In July, five of 161 (3.1\%) deermice Peromyscus maniculatus were positive. Specimens which tested positive were all captured in or around human habitation at disparate locations, namely, Beaver Creek $(n=2)$, the Highlands, Colter Bay, and the JDR Ranger Station. There was one specimen each of Microtus montanus and $M$. pennsylvanicus which tested positive, the first from 
a meadow where there had been no positive specimens from October, 1994, and the latter from a site not sampled in 1994.

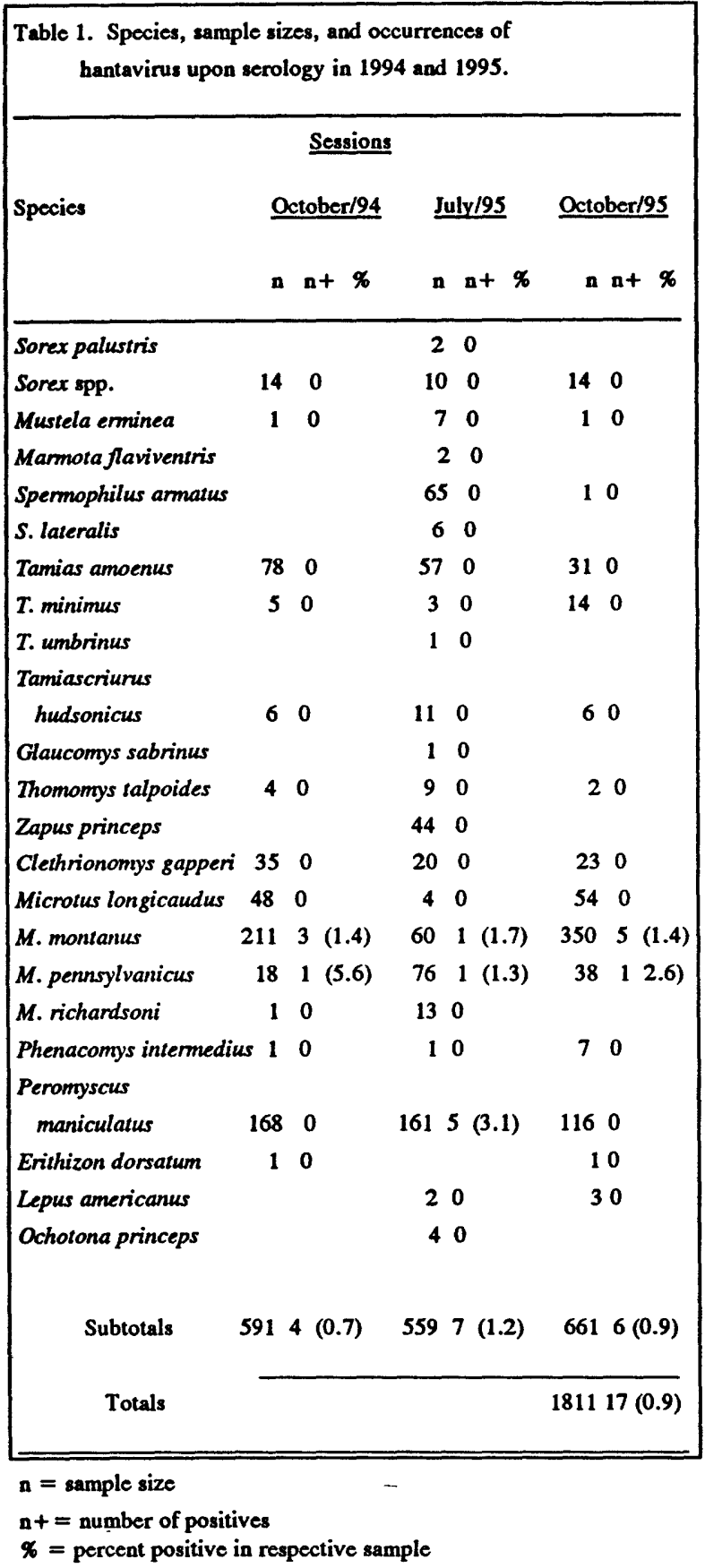

In October, no specimen of Peromyscus maniculatus tested positive, but there were five Microtus montanus which tested positive. Three were from two sites proximate to Flagg Ranch where positive specimens were secured in 1994.
One was from the site where a positive specimen was obtained in July, 1995. One was from the Elk Ranch site where $M$. pennsylvanicus had tested positive in October, 1994.

The only other species which tested positive for hantavirus in October was Microtus pennsylvanicus. The one positive specimen was trapped at the Elk Ranch site where one positive $M$. pennsylvanicus was obtained in October, 1994 and another positive $M$. montanus was also captured in October, 1995.

Of the five specimens of Peromyscus maniculatus which tested positive for hantavirus, four were reproductively active adults. Six of the eight specimens of Microtus spp. which tested positive were also adults.

Tests for plague and PCR examination of the lungs of serologically hantavirus-positive specimens have not been completed.

\section{DISCUSSION}

The numbers of Microtus montanus in the overall metapopulation increased from 1993 to 1994 and again from 1994 to 1995 . Disparate trends in the smaller populations are to be expected with the respective small sample sizes. There was an increase from 1994 to 1995 in the number of reproductively active parous Microtus montanus females. Fall breeding had not been extensive in 1994. The correlation of increasing fall breeding and population numbers found in 1995 is typical of the increase phase of population growth among microtine rodents (Krebs and Myers, 1974). There was additional support for the correlation of continued fall breeding with operational sex ratios characterized by a relatively large number of adult males, a pattern conducive to social maintenance of breeding (Jannett, 1984a, 1984b). Among higher population numbers of $M$. montanus in 1996, this pattern would perhaps be even more apparent.

The finding of Peromyscus maniculatus testing positive for hantavirus was significant. This species is the primary reservoir for the SNV strain of hantavirus in the western United States (Childs et al., 1994). The strain present in the Jackson Hole specimens is currently assumed to be SNV (S.T. Nichol, personal commmunication), of considerable significance to human health. 
The incidence of Peromyscus maniculatus testing positive for hantavirus was low in the total sample. However, the positive specimens were widely distributed and all were near or in human habitation.

There was a distinct pattern of foci for the occurrence of hantavirus among voles, both Microtus montanus and $M$. pennsylvanicus. All specimens which tested positive in 1994 and 1995 came from only five sites. Samples have been made at four of the five sites in each of two or three of the sampling sessions, and each of these four sites has yielded positive specimens in two sessions.

Current research suggests that, within a species carrying hantavirus, older individuals are more likely than younger animals to test positive (J. Mills, personal communication). This study supports that pattern. Current analyses of the specimens suggest a disproportionately higher incidence among the adults. Younger animals may have the virus, as identified by PCR, but serologically test negative (Childs et al., 1994). Therefore, hantavirus may be more widespread among the subadults in Jackson Hole than serological testing would indicate.

\section{SPECIMEN DEPOSITION}

Specimens collected are in the collections of the Science Museum of Minnesota. Lung tissues are in the frozen tissue collection of the Bell Museum of Natural History, St. Paul.

\section{$\uparrow \quad$ ACKNOWLEDGMENTS}

I thank Grand Teton National Park for permission to work in the Park and for in-kind staff support, and the University of Wyoming-National Park Service Research Center for its hospitality, the use of traps, and a grant. I also thank the Grand Teton Natural History Association for a grant. This work was also supported by the Science Museum of Minnesota and the Centers for Disease Control and Prevention. I thank Neil J. Vanderbosch for assistance in the field, and Mary Beth Batiste (NPS) for collecting specimens.

\section{LITERATURe CiTED}

Childs, J.E., T.G. Ksiazek, C.F. Spiropoulou, J.W. Krebs, S. Morzunov, G.O. Maupin, K.L. Gage, P.E. Rollin, J. Sarisky, R.E. Enscore, J.K. Frey, C.J. Peters, and S.T. Nichol. 1994. Serologic and genetic identification of Peromyscus maniculatus as the primary rodent reservoir for a new hantavirus in the southwestern United States. J. Infec. Dis., 169: 1271-1280.

Gourley, R.S. and F.J. Jannett, Jr. 1975. Pine and montane vole age estimates from eye lens weights. J. Wildl. Manage., 39: 550-556.

Jannett, F.J., Jr. 1984a. Reproduction of the montane vole, Microtus montanus, in subnivean populations. Special Publ. Carnegie Mus. Nat. Hist., 10: 215-224.

Jannett, F.J., Jr. 1984b. Sex ratios and late fall breeding in the montane vole, Microtus montanus. Amer. Zool., 24: 3A.

Krebs, C.J. and J.H. Myers. $1974 . \quad$ Population cycles in small mammals. Adv. Ecol. Res., 8: 267-399. 